\title{
Effects of Trenches with Organic Matter and KCL Fertilizer on Growth and Yield of Upland Rice in Eucalyptus Agroforestry System
}

DOI: 10.18196/pt.2020.121.114-125

\author{
Putri Ratnasari ${ }^{1 *}$, Tohari ${ }^{1}$, Eko Hanudin ${ }^{2}$, and Priyono Suryanto ${ }^{3}$ \\ ${ }^{1}$ Department of Agronomy, Faculty of Agriculture, Universitas Gadjah Mada, \\ ${ }^{2}$ Department of Soil Science, Faculty of AgricultureUniversitas Gadjah Mada, \\ ${ }^{3}$ Department of Silviculture, Faculty of Forestry, Universitas Gadjah Mada, \\ Bulaksumur, Yogyakarta, Indonesia 55281 \\ *Corresponding author, email: putriratnasari190@gmail.com
}

\begin{abstract}
Rice production can be improved through extensification using sub-optimal lands. One type of land that can be used for extensification of rice production in D.I. Yogyakarta is eucalyptus agroforestry system in Playen, Gunung Kidul. Besides expanding the land use, it can also increase farmers'income and ecological functions. However, this system has limiting factors such as the limited availability of water, which only relies on rain. Thus, proper water management and fertilization are necessary to fulfill water and nutrient requirements for rice growth. This study aimed to determine the effects of the application of trenches with organic matter and the doses of $\mathrm{KCl}$ on the growth and yield of upland rice (Situ Patenggang) in eucalyptus agroforestry systems. The study was conducted at the Menggoran Forest Management Resort, Bleberan, Playen, Gunung Kidul in March-August 2018. The study was arranged in a split plot design with three blocks as replications. The first factor was the application of trenches with organic matter, while the second factor was KCl fertilizer at. various doses. The data obtained were analyzed using analysis of variance (ANOVA) at the level of 5\%. The optimal dose of KCl fertilizer was determined by regression. The results showed that both factors had a positive effect on soil moisture content, growth, physiology, and yields of upland rice. The treatments significantly increased the availability of water in the soil, thereby supporting the growth and yield of upland rice.

Keywords: Agroforestry, Eucalyptus, KCl, Situ Patenggang, Organic Trenches
\end{abstract}

\begin{abstract}
ABSTRAK
Produksi padi dapat diupayakan melalui ekstensifikasi, yaitu dengan penggunaan lahan-lahan yang belum dimanfaatkan. Salah satu lahan yang dapat digunakan untuk ekstensifikasi padi di D.lYYogyakarta adalah lahan kayu putih di Playen (sistem agroforestri). Selain untuk meningkatkan penggunaan lahan, dapat juga meningkatkan pendapatan petani dan fungsi ekologis. Namun, sistem ini memiliki faktor pembatas yaitu ketersediaan air yang hanya mengandalkan air hujan sehingga perlu pengelolaan air dan pemupukan yang tepat untuk memenuhi kebutuhan air dan unsur hara untuk mendukung pertumbuhannya. Penelitian bertujuan mengetahui pengaruh penggunaan parit berbahan organik dan takaran KCl terhadap pertumbuhan dan hasil padi gogo (Situ Patenggang) pada sistem agroforestri kayu putih. Penelitian dilaksanakan di Resort Pengelolaan Hutan Menggoran, Bleberan, Playen, Gunung Kidul pada bulan Maret-Agustus 2018. Penelitian disusun berdasarkan rancangan split plot dengan 3 blok sebagai ulangan. Faktor pertama adalah penggunaan parit berbahan organik, sedangkan takaran KCl sebagai faktor kedua. Data yang diperoleh dianalisis dengan menggunakan analisis varian (Anova) dan regresi untuk memperoleh kombinasi perlakuan terbaik. Hasil menunjukkan kedua perlakuan berpengaruh positif terhadap kadar lengas, pertumbuhan, fisiologis, dan hasil padi gogo dibandingkan tanpa perlakuan. Hal ini disebabkan karena ketersediaan air menjadi lebih terpenuhi, sehingga mendukung pertumbuhan dan hasil yang optimal.
\end{abstract}

Kata Kunci: Parit Organik, KCl, Situ Patenggang, Agroforestri, Kayu Putih

\section{INTRODUCTION}

National rice consumption increased by an non-agriculture, extensification is more directed to average increase of $0.5 \%$ / year, namely $98.11 \mathrm{~kg}$ sub-optimal lands, such as peat land, coastal sandy / capita / year in 2015, $98.39 \mathrm{~kg}$ / capita / year land, dry land, acid land, and swamp land. One of in 2016, and $98.61 \mathrm{~kg} /$ capita / year in 2017 the usable lands that can be used for extensification (Indonesian Ministry of Agriculture, 2017). To of rice in D.I. Yogyakarta is eucalyptus forest land meet these needs, it is necessary to increase rice in Playen, Gunung Kidul. The crop cultivation production through intensification and extensifica- by combining rice with eucalyptus is called the tion. Due to land conversion from agriculture to eucalyptus-rice agroforestry system. 
This system can increase profits, both economically and ecologically. In this system, food crops are planted between forest plants, thereby increasing the income of farmers from both forest plants and food crops. This is consistent with research by Puspasari et al. (2017), stating that independent forest activities (without food crops) provide lower income compared to when combined with food crops due to the higher number of plants per land area. Agroforestry can also diversify the range of outputs to increase self-sufficiency. Diversification can reduce the loss of income that may occur, especially due to bad weather or the influence of biological factors and market factors. Apart from its economic function as one of the main objectives, agroforestry also plays a role in maintaining hydrological functions through the process of interception of rainwater, reducing the power of rainwater, water infiltration, water absorption and landscape drainage. In the field of conservation, agroforestry plays a role in the preservation of plant genetic resources, animal habitats, soil and water conservation and maintaining the balance of biodiversity (Widianto, 2013).

The obstacle of rice planting on agroforestry systems is the limited availability of water, which only relies on rainfall, causing rice cultivation to be quite risky. Rice plants are very sensitive to drought stress, hence it is necessary to apply proper water management by making trenches containing organic matter to increase rainwater infiltration. Trench with organic matter is a rainwater harvesting technology that is designed to increase the entry of water into the soil through the infiltration and filling of water bags in the basin and to reduce water loss through evapotranspiration (Subagyono et al., 2017). Rainwater harvesting is an act of collecting rainwater to be channeled into temporary shelters, which at any time can be used to irrigate cultivated plants. Therefore, with this method, the water needs during the dry season in dry areas can be fulfilled from the harvested rainwater. The level of soil moisture in the presence of rainwater harvesting system will increase by about $5 \%$ at a depth of 0-30 cm (Rusli and Heryana, 2015).

The trenches used for water harvesting are also given organic matter because this organic matter provides a lot of benefits, including to reduce evaporation from harvested water. Based on Dien et al. (2017), organic matter provided in the soil will experience a process of weathering and remodeling, which in turn will produce humus. Humus with Hydrophilic colloid layer can agglomerate and become gel, therefore the topsoil is important in the crumbly soil. Humus is so important that the soil will not dry quickly during dry season because it has high water holding capacity. Humus can hold water four to six times its own weight. By holding water, humus can reduce evaporation through soil. Organic matter helps bind the clay grains to form bigger grain bonds, thereby enlarging the water spaces between the grain bonds (Fayyaz et al., 2013). Therefore, the higher organic matter content will result in the higher moisture content in the soil. Organic matter in the soil can absorb water 2-4 times of its weight, playing a role in water transport. The advantages of adding organic fertilizers to the soil are not only in their nutrient element contents but also in their other roles, including improving the structure, , aeration, and water holding capacity of the soil, as well as affecting soil temperature and providing the improved substances for plant growth (Zain et al., 2014).

The organic matter used was corn waste that was the residue from the previous Besides, corn waste can also be used as organic matter for farming system. The parts of corn plant used as organic matter are the leaves, stems, and cobs, which are usually thrown away or resolved at the planting location even though those organic matters contain 
Table 1. Gap analysis of upland rice cv. Situ Patenggeng

\begin{tabular}{|c|c|c|c|c|}
\hline Area & Actual Result & Potential Result & Difference & Action Plan \\
\hline $\begin{array}{c}\text { Eucalyptus } \\
\text { Agroforestry System, } \\
\text { Playen, Gunung Kidul }\end{array}$ & $\begin{array}{l}\text { The actual yield of } \\
\text { upland rice in eucalyptus } \\
\text { agroforestry system is } 0.5 \\
-3.068 \text { ton.ha-1 }\end{array}$ & $\begin{array}{l}\text { The potential yield of } \\
\text { upland rice in eucalyptus } \\
\text { agroforestry system is } \\
2.08-4 \text { ton. ha }^{-1}\end{array}$ & $\begin{array}{c}\text { The difference between actual } \\
\text { and potential results is } 1.58 \text { - } \\
0.932 \text { ton.ha }{ }^{-1}\end{array}$ & $\begin{array}{l}0,100 \text {, and } 200 \mathrm{~kg} \cdot \mathrm{ha}^{-1} \mathrm{KCl} \\
\text { fertilizerWithout trench and } \\
\text { trench with organic matter }\end{array}$ \\
\hline
\end{tabular}

important nutrients such as nitrogen, phosphorus, and potassium. Corn organic matter is the building block for granulation in the soil and is very important in tye soil aggregates (Ernita et al., 2017).

According to Table 1, the upland rice cv. Situpatenggang used in this research located in Eucalyptus Agroforestry System, Playen, Gunung Kidul has an actual yield of $0.5-3.068$ ton.ha ${ }^{-1}$ (Tarigan et al., 2013). Meanwhile, according to the Ministry of Agriculture (2013), the potential yield of the upland rice in eucalyptus agroforestry system is 2.08 - 4 ton.ha ${ }^{-1}$. Thus, the gap between actual and potential yield is $1.58-0.932$ ton.ha ${ }^{-1}$. In this study, there were two factors to be tested, consisting of KCL fertilizer (at a doses of 0, 100, and $200 \mathrm{~kg} \cdot \mathrm{ha}^{-1}$ ) and the application of trenches (without trench and trench with organic matter)

Potassium affects water content in plants, photosynthesis, and photosynthate translocation. Therefore, $\mathrm{K}$ fertilization can increase yield, especially when the moisture content of the soil is low. The role of $\mathrm{K}$ is related to the regulation of water status in plant tissue, stomatal regulation and assimilates transport (Wahyuti, 2011). The dose of $\mathrm{KCl}$ fertilizer is based on $\mathrm{K}$ status in the soil. In soil with a low, moderate, and high $\mathrm{K}$ level, the required dose of $\mathrm{KCl}$ fertilizer is $100 \mathrm{~kg} \mathrm{ha}^{-1}$, while in the soil with moderate and high $\mathrm{K}$ level, the recommended $\mathrm{KCl}$ fertilizer is $50 \mathrm{~kg} \cdot \mathrm{ha}^{-1}$ (Asmin and La, 2014). In upland farming, optimal $\mathrm{KCl}$ fertilization is given gradually because when entering the generative phase, $\mathrm{K}$ fertilization encourages grain filling (Kartikawati and Nursyamsi, 2013). Accordingly, the application of $\mathrm{KCl}$ fertilizer and rainwater harvesting technology (using trenches with organic matter) is expected to fulfill the water needs of plants. Potassium increases the plant's drought resistance through its functions in stomatal regulation, osmoregulation, energy status, charge balance, protein synthesis, and homeostasis. Based on Zain et al. (204), in plants coping with drought stress, the accumulation of $\mathrm{K}^{+}$may be more important than the production of organic solutes during the initial adjustment phase, because osmotic adjustment through ion uptake like $\mathrm{K}^{+}$is more energy efficient. The lower water loss in plants well supplied with $\mathrm{K}^{+}$is due to a reduction in transpiration, which depends not only on the osmotic potential of mesophyll cells, but is also largely controlled by the opening and closing of stomata.

This study aimed to determine the effects of trenches with organic matter and $\mathrm{KCl}$ fertilizer doses, as well as to find out the highest yield of upland rice as affected by the interaction of trenches with organic matter and $\mathrm{KCl}$ fertilizer. This research is expected provide solution to overcome the drought that usually occurs in the research location. Thus, the decrease in the rice production during the dry season can be minimized. In addition, this research is expected to suggest the best combination of treatments for maximum yields, resulting minimum input (litter, ditch, and fertilizer) used in producing maximum yields.

\section{MATERIALS AND METHODS}

This study was conducted in March - August 2018 in plot 83 of RPH Menggoran, BDH Playen of KPH Yogyakarta and Laboratories in Faculty of Agriculture, Universitas Gajah Mada. Gunungkidul Regency is dominated by mountains the western 
Table 2. Environmental conditions of the research location

\begin{tabular}{|c|c|c|c|c|}
\hline Month & Rainfall (mm) & Humidity (\%) & Average Temperature $\left({ }^{\circ} \mathrm{C}\right)$ & Wind Velocity $\left(\mathrm{m} \cdot \mathrm{s}^{-1}\right)$ \\
\hline March & 407 & 83 & 26.4 & 3 \\
\hline April & 138 & 82 & 27.0 & 2 \\
\hline May & 21 & 79 & 26.5 & 2 \\
\hline June & - & 80 & 25.7 & 3 \\
\hline July & - & 81 & 26.2 & 2 \\
\hline August & - & 81 & 27.2 & 3 \\
\hline Average & 94,3 & 81 & 26.5 & 2.5 \\
\hline
\end{tabular}

part of the Pegunungan Seribu or the Pegunungan when pests and diseases were considered harmful. Kapur Selatan that stretches from the south of The doses of organic matter were based on the size Java Island to the east to Tulungagung Regency. of the trench ( $2 \mathrm{~kg}$ of corn waste in each trench). Gunungkidul are formed from limestone. Most of Anthracol was used to treat grasshoppers and the areas in Gunungkidul Regency are highlands leafhoppers. This study was arranged in a split plot with land conditions that have different slopes. Based on the research results, the following is data on climatic conditions in the studied area. design with three blocks as replications, in which the main plot (vertical plot) was the application of trenches with organic matter, and the sub plot

The research location had relatively low rainfall during the research period, reaching an average of $94.33 \mathrm{~mm}$, while the water requirement for the rice plants was $110-115 \mathrm{~mm}$. Therefore, it is necessary to have a report on the need for adequate plant water. The average humidity at the research location was $81 \%$ (humid), with an average temperature of 26.5 $0 \mathrm{C}$ and an average wind speed of $2.5 \mathrm{~m} \cdot \mathrm{s}^{-1}$ (Table 2).

The materials used were upland rice seeds $\mathrm{cv}$. Situ Patenggang, $\mathrm{KCl}$ fertilizer, pesticides, and observation materials. The tools used were cultivation tools and data collection. According to Mawardi et al. (2016), Situ Patenggang cultivar is a variety that is resistant to dry conditions. The yield potential of Situ Patenggang cultivar is 6 ton.ha ${ }^{-1}$ and 4.5 ton.ha ${ }^{-1}$, in paddy fields and upland, repectively. In several studies, the yield of Situ Patenggang cultivar in upland was between 2.08 - 4 ton.ha ${ }^{-1}$. $\mathrm{KCl}$ fertilizer at three different doses, namely 0 kg.ha $a^{-1}$ (without KCl), 100 kg.ha ${ }^{-1}$, and 200 kg.ha-1, was applied three times, which were before planting, 3 weeks after planting, and at the beginning of the generative phase. Pesticides were applied (horizontal plot) was the dose of $\mathrm{KCl}$ fertilization. The organic matter used was crop waste, which was the residue from the previous corn planting that was already chopped into small pieces and put into the trenches.

The data collected included soil moisture content, growth component (leaf area, root dry weight, root length, root area, and shoot dry weight), physiology (chlorophyll, photosynthetic rate, and proline content), and yield components (filled grain percentage, weight of 1000 seeds, and productivity). Plant growth data were obtained by observing and measuring the variables every two weeks, physiological data were recorded at the beginning of the generative phase, while the yield data were obtained at harvest. The data were analyzed using analysis of variance (ANOVA) at the level of 5\%, and regression analysis was made to determine the optimal dose of $\mathrm{KCl}$ fertilizer. The data showing significant differences according to the analysis of variance were further tested using Tukey HSD test. 


\section{RESULTS AND DISCUSSIONS}

The soil order in the research location is Vertisol. The typical characteristics of Vertisol include the fractures that are periodically open and closed, micro-reliefs and slickenside at a depth of $40 \mathrm{~cm}$, clay content of $30 \%$ or more on the entire horizon which lies between a depth of $50 \mathrm{~cm}$, and a Lithic contact (Soil Survey Staff, 2014).

Table 3. Soil analysis of the research location

\begin{tabular}{lcc}
\hline Analysis & Value & Category \\
\hline Soil texture & & Vertisol Lithic Haplustert \\
\hline Soil physical properties & & \\
a. Soil texture & & \\
Sand (\%) & 14.56 & Clay \\
Dust (\%) & 11.97 & \\
Clay & 73.47 & Low \\
\hline Soil chemicalk properties & & Moderate \\
Organic Matter (\%) & 2.19 & Low \\
C/N ratio (\%) & 11.55 & \\
Level of K availability (\%) & 16.71 & \\
\hline
\end{tabular}

Based on the observations of the soil physical properties in the field and in the laboratory (Table 3 ), the soil has a clay texture with a ratio of $14.56 \%$ sand fraction, $11.97 \%$ silt and $73.47 \%$ clay. The soil classified in clay texture has the ability to absorb and store more water than other texture groups. Clay is the smallest size soil particle. Clay has the ability to hold both nutrients and water that can be used by plants. It creates very small pore spaces, resulting in poor aeration and poor water drainage. Clay forms hard clumps when dry, and it is sticky when wet (Dotto et al., 2016). The content of organic matter $(2.19 \%)$ was classified as low due to the absence of land cover vegetation. The lack of addition of organic matter from vegetation litter caused a low organic matter content. Proportion of carbon and nitrogen content in the soil can be known through the $\mathrm{C} / \mathrm{N}$ ratio, which in this study, the $\mathrm{C} / \mathrm{N}$ ratio of the soil was in moderate conditions (11.55\%). The availability of $\mathrm{K}$ was relatively low $(16.71 \%) . \mathrm{K}$ is absorbed by plants from the soil in the form of $\mathrm{K}^{+}$ions. The low content of low-potassium is thought to be due to the influence of calcium $(\mathrm{Ca} 2+)$ content, which has a main material in the form of limestone. The calcareous nature of limestone in vertisol, which is dominated by smectite minerals, greatly influences the availability of soil nutrients, especially potassium and phosphorus (Virmani et al., 2002).

Planting upland rice in eucalyptus forests is classified as a simple agroforestry system, namely an agricultural system in which trees are intercropped with one or more types of annual crops. The benefit of agriculture (upland rice) towards forestry (eucalyptus) is to know the right planting system, so that it can produce more products, reduce land erosion, and increase product diversity. On the other hand, the presence of eucalyptus provides benefits to rice

Table 4. Dry weight of leaf and branch of eucalyptus (kg)

\begin{tabular}{lcc}
\hline Treatment & Leaf Dry Weight $(\mathrm{kg})$ & Branch Dry Weight $(\mathrm{kg})$ \\
\hline Trench & & $1.58 \mathrm{a}$ \\
Without trench & $0.99 \mathrm{a}$ & $1.60 \mathrm{a}$ \\
\hline Trench with organic matter & $0.90 \mathrm{a}$ & $1.42 \mathrm{p}$ \\
\hline Dose of $\mathrm{KCl}\left(\mathrm{kg}_{\mathrm{h}} \mathrm{ha}^{-1}\right)$ & & $1.57 \mathrm{p}$ \\
$0 \mathrm{~kg} \cdot \mathrm{ha}^{-1}$ & $0.85 \mathrm{p}$ & $1.74 \mathrm{p}$ \\
$100 \mathrm{~kg} \cdot \mathrm{ha}^{-1}$ & $0.93 \mathrm{p}$ & $(-)$ \\
\hline
\end{tabular}

Notes: Values followed by the same letters in the same column and the same treatment are not significantly different based on Tukey at $5 \%$. The sign (-) shows no interaction between the factors tested. 
Table 5. Soil moisture content at 12 weeks after planting (\%)

\begin{tabular}{lcccc}
\hline \multirow{2}{*}{ Treatment } & \multicolumn{3}{c}{ Dose of KCl } & Mean \\
\cline { 2 - 4 } & 0 kg.ha-1 & $100 \mathrm{~kg}^{-\mathrm{ha}^{-1}}$ & $200 \mathrm{~kg}^{-\mathrm{ha}^{-1}}$ & 41.47 \\
\hline Without trench & $40.80 \mathrm{c}$ & $41.58 \mathrm{~b}$ & $42.02 \mathrm{~b}$ & 42.45 \\
Trench with organic matter & $41.60 \mathrm{~b}$ & $42.15 \mathrm{~b}$ & $43.61 \mathrm{a}$ & $(+)$ \\
\hline Mean & 41.2 & 41.87 & 42.82 & \\
\hline
\end{tabular}

Notes: Values followed by the same letters in the same column and the same treatment are not significantly different based on Tukey at $5 \%$. The $(+)$ sign shows an interaction between the factors tested.

Table 6. Leaf area of upland rice at 12 weeks after planting $\left(\mathrm{cm}^{2}\right)$

\begin{tabular}{|c|c|c|c|c|}
\hline \multirow{2}{*}{ Treatment } & \multicolumn{3}{|c|}{ Dose of $\mathrm{KCl}$} & \multirow{2}{*}{ Mean } \\
\hline & 0 kg.ha-1 & $100 \mathrm{~kg} \cdot \mathrm{ha}^{-1}$ & $200 \mathrm{~kg} \cdot \mathrm{ha}^{-1}$ & \\
\hline Without trench & $1115.33 c$ & $1438.28 c$ & $1854.26 \mathrm{~b}$ & 1469.29 \\
\hline Trench with organic matter & $1299.67 \mathrm{c}$ & 2209.48 a & $2512.06 \mathrm{a}$ & 2007.07 \\
\hline Mean & 1207.5 & 1823.88 & 2183.16 & $(+)$ \\
\hline
\end{tabular}

Notes: Values followed by the same letters in the same column and the same treatment are not significantly different based on Tukey at $5 \%$. The $(+)$ sign shows an interaction between the factors tested.

plants because it can protect plants from extreme winds and temperatures, reduce pests, maintain moisture, and increase soil moisture content (Nuberk, 2008). In addition, the existence of this system can also make natural preservation more secure and neat (Saikia et al., 2017).

There was no significant effect of all treatments on the dry weight of eucalyptus leaves and branches (Table 4). The application of trenches with organic matter and $\mathrm{KCl}$ fertilizer doses did not give a significant effect because the trenches and cultivation plants were located too far from eucalyptus plants, so that they did not give any influence on the dry weight of the eucalyptus leaves and canopy.

The treatment combination of trenches with organic matter and $\mathrm{KCl}$ at a dose of $200 \mathrm{~kg} \cdot \mathrm{ha}^{-1}$ resulted in the highest soil moisture content of $14 \%$, in which the moisture content of the soil ranged from $41-42 \%$ (Table 5). This result is due to the function of the trenches to hold water. Besides, organic matter in the trenches serves to reduce evaporation of the stored water. Thus, the application of trenches with organic matter could increase the moisture content of the soil.

The treatment combination of trenches with organic matter and $\mathrm{KCl}$ at the highest dose resulted in the highest leaf area at 12 weeks after planting (Table 6). The wider the leaf, the more sunlight is captured to be used in photosynthesis. In addition, it can increase the number of stomata in the leaves (Idris et al., 2017). Meanwhile, treatment without trenches and without $\mathrm{KCl}$ fertilization resulted in the lowest leaf area compared to other treatments. Leaf area and productivity rate per unit leaf area will affect the ability of leaves to produce photosynthate products. Thus, the wider the leaf, the greater the photosynthate products (Haryanti, 2014).

The treatment combination of trenches with organic matter and $\mathrm{KCl}$ at a dose of $200 \mathrm{~kg} \mathrm{ha}^{-1}$ resulted in the highest dry weight of branches and root compared to other treatments at 12 weeks after planting (Table 7), but not significantly different those resulted by the treatment combination of trenches with organic matter and $\mathrm{KCl}$ at a dose of $100 \mathrm{~kg} \mathrm{ha}^{-1}$. The optimum availability of nitrogen, phosphorus, potassium, and magnesium for plants can increase chlorophyll content, thereby increasing photosynthetic activity to produce more assimilates, which support the dry weight of the plant (Sitorus et al., 2014). Dry weight is the result of photosynthesis in a plant, which mean this treatment combination could optimize photo- 
Table 7. Root and branch dry weight of upland rice at 12 weeks after planting (g)

\begin{tabular}{|c|c|c|c|c|}
\hline \multirow{2}{*}{ Treatment } & \multicolumn{3}{|c|}{ Dose of $\mathrm{KCl}$} & \multirow{2}{*}{ Mean } \\
\hline & $0 \mathrm{~kg} \cdot \mathrm{ha}^{-1}$ & $100 \mathrm{~kg} \cdot \mathrm{ha}^{-1}$ & $200 \mathrm{~kg} \cdot \mathrm{ha}^{-1}$ & \\
\hline \multicolumn{5}{|c|}{----- Branch dry weight (g) ----- } \\
\hline Without trench & $41.09 \mathrm{~d}$ & $43.76 \mathrm{~cd}$ & $47.32 \mathrm{~b}$ & 44.06 \\
\hline Trench with organic matter & $45.26 \mathrm{bc}$ & $53.79 \mathrm{a}$ & $55.9 \mathrm{a}$ & 51.65 \\
\hline Mean & 43.18 & 48.78 & 51.61 & $(+)$ \\
\hline \multicolumn{5}{|c|}{---- Root dry weight (g) ----- } \\
\hline Without trench & $20.73 d$ & $22.87 \mathrm{c}$ & $25.45 b$ & 23.02 \\
\hline Trench with organic matter & $21.96 c$ & $26.70 \mathrm{a}$ & $26.59 \mathrm{a}$ & 25.08 \\
\hline Mean & 21.35 & 24.79 & 26.02 & $(+)$ \\
\hline
\end{tabular}

Notes: Values followed by the same letters in the same column and the same treatment are not significantly different based on Tukey at $5 \%$. The $(+)$ sign shows an interaction between the factors tested.

Table 8. Root length $(\mathrm{cm})$ and root area $\left(\mathrm{cm}^{2}\right)$ of upland rice at 12 weeks after planting

\begin{tabular}{|c|c|c|c|c|}
\hline \multirow{2}{*}{ Treatment } & \multicolumn{3}{|c|}{ Dose of $\mathrm{KCl}$} & \multirow{2}{*}{ Mean } \\
\hline & 0 kg.ha-1 & $100 \mathrm{~kg} \cdot \mathrm{ha}^{-1}$ & $200 \mathrm{~kg} \cdot \mathrm{ha}^{-1}$ & \\
\hline \multicolumn{5}{|c|}{---- Root length $(\mathrm{cm})$----- } \\
\hline Without trench & $150.46 \mathrm{c}$ & $181.20 \mathrm{~b}$ & $195.58 \mathrm{a}$ & 175.74 \\
\hline Trench with organic matter & $171.23 b$ & $199.61 \mathrm{a}$ & $201.05 \mathrm{a}$ & 190.63 \\
\hline Mean & 160.83 & 190.41 & 353.89 & $(+)$ \\
\hline \multicolumn{5}{|c|}{---- Root area $\left(\mathrm{cm}^{2}\right)$----- } \\
\hline Without trench & $1140.05 d$ & $1396.75 b$ & $1616.94 \mathrm{a}$ & 1384.58 \\
\hline Trench with organic matter & $1293.48 c$ & $1678.08 \mathrm{a}$ & $1691.33 \mathrm{a}$ & 1554.30 \\
\hline Mean & 1216.77 & 1537.42 & 1654.135 & $(+)$ \\
\hline
\end{tabular}

Notes: Values followed by the same letters in the same column and the same treatment are not significantly different based on Tukey at $5 \%$. The $(+)$ sign shows an interaction between the factors tested.

synthesis and produce sufficient assimilates to be was significantly different from those resulted by used later in the generative phase. This treatment other treatments (Table 8). Meanwhile, the treatcombination also helped rice plants maximize the ment without trenches with organic matter and panicle formation process in accordance with the without $\mathrm{KCl}$ fertilization resulted in the shortest role of potassium as an element that plays a role in roots length $(150.46 \mathrm{~cm})$. The longer the root, the improving plant generative organs (Hasanuzzaman et al., 2018), thereby increasing the dry weight of the shoots, along with increasing panicle number and length and grain weight. The combination of other treatments that showed good results was the treatment of without trenches combined with $\mathrm{KCl}$ at a dose of $200 \mathrm{~kg} \cdot \mathrm{ha}^{-1}$. The treatment resulting in the lowest dry weight of the shoot is without trenches and without $\mathrm{KCl}$ fertilization.

farther the reach of the root. Root interception occurs as a result of root growth from short to be long, from not branching to be branched, and from branching a little to be branched a lot. As a result of this growth, the roots formed reached parts of the growing media that was not reachable before. Increasing the range of course increases the elements nutrients and water that can come into contact with the surface of the root hairs and

The treatment combination of trenches with organic matter and $\mathrm{KCl}$ at a dose of $200 \mathrm{~kg} \cdot \mathrm{ha}^{-1}$ resulted the longest root length $(201.05 \mathrm{~cm})$ that then get it absorbed by plant roots (Febriyono et al., 2017). 
Based on Table 9, both factors have no interaction, but they have a positive effect on the chlorophyll content. Treatment without trenches resulted in less water availability, making the plants experience drought stress. Plants that lack water experience a decrease in turgor pressure, causing a decrease in chlorophyll content. Meanwhile, the treatment of $\mathrm{KCl}$ fertilization at a dose of 200 $\mathrm{kg} . \mathrm{ha}^{-1}$ gave a higher chlorophyll content compared to other $\mathrm{KCl}$ doses. Potassium has a role in the process of opening and closing of stomata, which is influenced by $\mathrm{CO}_{2}$ content and the process of photosynthesis. Potassium deficiency results in low chlorophyll content. Decreased chlorophyll content and chlorophyll a / b ratio are indicators of chloroplast disturbance (Astuti et al., 2019). According to the research conducted by Jia et al. (2008), the chlorophyll content of rice plants decreased under moderate potassium deficiency level $\left(5 \mathrm{mg} \mathrm{KL}^{-1}\right)$, while under normal potassium dose $\left(40 \mathrm{mg} \mathrm{KL}^{-1}\right)$, the chlorophyll content was higher.

The application of trenches with organic matter increased the rate of photosynthesis (Table 10). Trenches with organic matter increased the moisture content in the soil, so cells become more turgor. In addition, water functions as one of the raw materials in light reactions in photosynthesis. Water molecules will be broken down by Manganese ( $\mathrm{Mn})$, forming $\mathrm{H}^{+}$ions in the thylakoid lumen (Baglieri et al., 2014). The lower the availability of water, the lower the photosynthetic rate (Table 10 ), in which the application of water harvesting system could increase the rate of photosynthesis. The trenches with organic matter increased the

Table 9. Chlorophyll content of upland rice at 12 weeks after planting (mg.g-1 plant)

\begin{tabular}{|c|c|c|c|}
\hline Treatment & Chlorophyll a & Chlorophyll b & Total Chlorophyll \\
\hline \multicolumn{4}{|l|}{ Trench } \\
\hline Without trench & $19.03 b$ & $8.72 b$ & $27.74 b$ \\
\hline Trench with organic matter & $25.10 \mathrm{a}$ & $11.88 \mathrm{a}$ & $36.98 \mathrm{a}$ \\
\hline \multicolumn{4}{|l|}{ Dose of KCl (kg.ha-1) } \\
\hline $0 \mathrm{~kg} \cdot \mathrm{ha}^{-1}$ & $15.7 \mathrm{~b}$ & $6.79 c$ & $22.49 b$ \\
\hline $100 \mathrm{~kg} \cdot \mathrm{ha}^{-1}$ & $24.17 \mathrm{a}$ & $11.36 b$ & $35.53 \mathrm{a}$ \\
\hline $200 \mathrm{~kg} \cdot \mathrm{ha}^{-1}$ & $26.31 \mathrm{a}$ & $12.75 \mathrm{a}$ & $39.06 \mathrm{a}$ \\
\hline Trench*Dose of $\mathrm{KCl}$ & $(-)$ & $(-)$ & $(-)$ \\
\hline
\end{tabular}

Notes: Values followed by the same letters in the same column and the same treatment are not significantly different based on Tukey at $5 \%$. The sign (-) shows no interaction between the factors tested.

Table 10. Photosynthetic rate and proline content of upland rice

\begin{tabular}{|c|c|c|c|c|}
\hline \multirow{2}{*}{ Treatment } & \multicolumn{3}{|c|}{ Dose of $\mathrm{KCl}$} & \multirow{2}{*}{ Mean } \\
\hline & $0 \mathrm{~kg} \cdot \mathrm{ha}^{-1}$ & $100 \mathrm{~kg} \mathrm{ha}^{-1}$ & $200 \mathrm{~kg} \cdot \mathrm{ha}^{-1}$ & \\
\hline \multicolumn{5}{|c|}{---- Rate photosynthesis $\left(\mu \mathrm{mol} \mathrm{CO}_{2} \cdot \mathrm{cm}^{2} . \mathrm{s}^{-1}\right)$----- } \\
\hline Without trench & $89.79 d$ & $124.70 \mathrm{c}$ & $154.25 b$ & 122.91 \\
\hline Trench with organic matter & $111.62 c$ & $175.02 \mathrm{a}$ & $180.76 \mathrm{a}$ & 155.8 \\
\hline Mean & 100.71 & 149.86 & 167.51 & $(+)$ \\
\hline \multicolumn{5}{|c|}{----- Proline content $\left(\mu \mathrm{mol} . g^{-1}\right)$----- } \\
\hline Without trench & $14.89 \mathrm{~d}$ & $6.64 \mathrm{~cd}$ & $4.22 c$ & 8.58 \\
\hline Trench with organic matter & $11.2 d$ & $3.76 b$ & $3.31 \mathrm{a}$ & 6.09 \\
\hline Mean & 13.05 & 5.2 & 3.77 & $(+)$ \\
\hline
\end{tabular}

Notes: Values followed by the same letters in the same column and the same treatment are not significantly different based on Tukey at $5 \%$. The $(+)$ sign shows an interaction between the factors tested. 
Table 11. Percentage of grain content (\%) and weight of 1000 seeds (g)

\begin{tabular}{|c|c|c|c|c|}
\hline \multirow{2}{*}{ Treatment } & \multicolumn{3}{|c|}{ Dose of $\mathrm{KCl}$} & \multirow{2}{*}{ Mean } \\
\hline & 0 kg.ha-1 & $100 \mathrm{~kg} \cdot \mathrm{ha}^{-1}$ & $200 \mathrm{~kg} \cdot \mathrm{ha}^{-1}$ & \\
\hline \multicolumn{5}{|c|}{----- Percentage of grain content (\%) ----- } \\
\hline Without trench & $79.81 \mathrm{c}$ & $82.27 \mathrm{c}$ & $85.52 b$ & 82.53 \\
\hline Trench with organic matter & $81.25 \mathrm{c}$ & $88.7 \mathrm{a}$ & $91.57 \mathrm{a}$ & 87.17 \\
\hline Mean & 80.53 & 85.49 & 88.55 & $(+)$ \\
\hline \multicolumn{5}{|c|}{---- Weight of 1000 seeds $(\mathrm{g})$----- } \\
\hline Without trench & $7.20 d$ & $10.03 c$ & $13.81 \mathrm{~b}$ & 10.35 \\
\hline Trench with organic matter & $8.78 c$ & $15.25 \mathrm{a}$ & $15.52 \mathrm{a}$ & 13.18 \\
\hline Mean & 7.99 & 12.64 & 14.67 & $(+)$ \\
\hline
\end{tabular}

Notes: Values followed by the same letters in the same column and the same treatment are not significantly different based on Tukey at $5 \%$. The $(+)$ sign shows an interaction between the factors tested.

moisture content in the soil, making them better. Thus, it causes the treatment without trenches to show a lower photosynthetic rate compared to the application of trenches with organic matter.

The lower rate of photosynthesis will inhibit the plant growth, resulting in the stunted plants, thereby decreasing the yield. The wider the leaves, the greater the yield. Leaf is the main photosynthetic organ in plants, in which the main plant metabolic processes occur, such as photosynthesis, transpiration, and $\mathrm{CO}_{2} / \mathrm{O}_{2}$ gas exchange. Sufficient plant needs for growth elements will stimulate plant height increase and new leaf formation. the longer and wider the leaf, the more the light absorption by the leaf, thus increasing the rate of photosynthesis. The increased rate of photosynthesis will encourage the growth and development of leaves so that the yield increases (Nurnasari and Djumali, 2010).

The treatment combination of trenches with organic matter and $\mathrm{KCl}$ at the highest dose (200 $\left.\mathrm{kg} \cdot \mathrm{ha}^{-1}\right)$ resulted in the lowest proline content (3.31 $\left.\mu \mathrm{mol} \mathrm{g}{ }^{1}\right)$. Meanwhile, the treatment without trenches and without $\mathrm{KCl}$ fertilization showed the highest proline content $\left(14.89 \mu \mathrm{mol} \mathrm{g}{ }^{1}\right)$, showing that the plants experienced stress. On the other hand, this result shows that potassium plays a role in helping plants cope the stress conditions, but when soil moisture conditions are available, potas- sium is only used for other metabolism so that the formation of proline continues run normally. The application of trenches with organic matter resulted in lower proline content compared to that without trenches and without $\mathrm{KCl}$. This suggests that potassium plays a role in helping plants cope stressful conditions. Research conducted by Bahrami-rad et al. (2017) showed the same result, reporting that foliar application of potassium could increase the proline content of tobacco leaves. Increased proline content as the result of potassium application is not clearly known yet. Potassium is thought to play a role in metabolism of several amino acids, and it is also thought to direct, directly or indirectly, role in the proline synthesis pathway. Potassium has specific role in the conversion of arginine to proline via increased enzyme activity arginase. Increased activity of the arginase enzyme occurs when the plants experience abiotic stress. The addition of potassium in plants can cause stress, thereby increasing arginase enzyme activity and increasing the arginine role in proline synthesis.

According to Cha-Um (2010), the high rate of photosynthesis will be able to form many assimilates used for cell enlargement and division, and a portion of the assimilates will be stored in the form of food reserves in the form of seeds. In line with this statement, the combination of trench 
Table 12. Productivity of upland rice (ton.ha-1)

\begin{tabular}{lcccc}
\hline \multirow{2}{*}{ Treatment } & \multicolumn{3}{c}{ Dose of KCl } & Mean \\
\cline { 2 - 4 } & $0 \mathrm{~kg} \cdot \mathrm{ha}^{-1}$ & $100 \mathrm{~kg} \cdot \mathrm{ha}^{-1}$ & $200 \mathrm{~kg} \cdot \mathrm{ha}^{-1}$ & \\
\hline Without trench & $0.432 \mathrm{~d}$ & $0.919 \mathrm{c}$ & $1.738 \mathrm{~b}$ & 1.030 \\
Trench with organic matter & $0.694 \mathrm{~cd}$ & $2.716 \mathrm{a}$ & $3.068 \mathrm{a}$ & 2.159 \\
\hline Mean & 0.563 & 1.818 & 2.403 & $(+)$ \\
\hline
\end{tabular}

Notes: Values followed by the same letters in the same column and the same treatment are not significantly different based on Tukey at $5 \%$. The $(+)$ sign shows an interaction between the factors tested.

treatment with organic matter and $\mathrm{KCl}$ at doses of 100 and $200 \mathrm{~kg} \cdot \mathrm{ha}^{-1}$ resulted in the highest photosynthetic rate, producing higher percentage of filled grain and 1000 seed weight compared to other treatments (Table 11). According to Tarigan et al. (2013) the weight of 1000 seeds of upland rice cv. Situ Patenggang can reach 23 grams, but in this study, the highest weight of 1000 seeds was only 15 grams. This result could be due to several factors, especially environmental factors inhibiting rice growth.

The treatment combination of trenches with organic matter and the highest dose of $\mathrm{KCl}$ (200 $\left.\mathrm{kg} \cdot \mathrm{ha}^{-1}\right)$ was able to produce the highest grain yield per hectare (3,068 ton.ha $\left.{ }^{-1}\right)$. In addition, grain yield per hectare is also influenced by the percentage of filled grain. This figure is lower than the potential of Situ Patenggang cultivar in paddy field, but is considered high at the research location because the average rice production is usually 3 tons.hect$\operatorname{are}^{-1}$. According to Ikhsan et al. (2017), the yield per hectare is determined by seed size, panicle length, number of grains per panicle, number of panicles, number of clumps, number of seeds, and weight of 1000 seeds. Characters are determined by genetic factors and environment. The previously mentioned characters are determined by those special genes activity and built by environment factors. The adaptation ability of plants to the environment is a trait controlled by the genes in plants, allowing plants to be able to produce relatively better at certain environment. Kobayasi (2014) stated that yield component in the form of a complex character controlled by a large number of cumulative, duplicate, and dominant genes are very helpful for the environment.

After the data of yield were obtained, the next step was to carry out regression analysis. The curves formed in the regression analysis might contain critical or extreme points. The critical point is the optimal point, which is the maximum or minimum stationary point in the curve. Based on the regression tests on upland rice productivity, an equation with quadratic curves was obtained from the interaction effect of the application of trenches with organic matter and $\mathrm{KCl}$ at a dose of $200 \mathrm{~kg} \cdot \mathrm{ha}^{-1}$ on the grain yield per hectare (ton.hectar ${ }^{-1}$ ), which is $Y($ grain per hectare $)=0.694+0.029 x-8.353 E-5$ $x^{2} R^{2}=0.983$ (Figure 1).

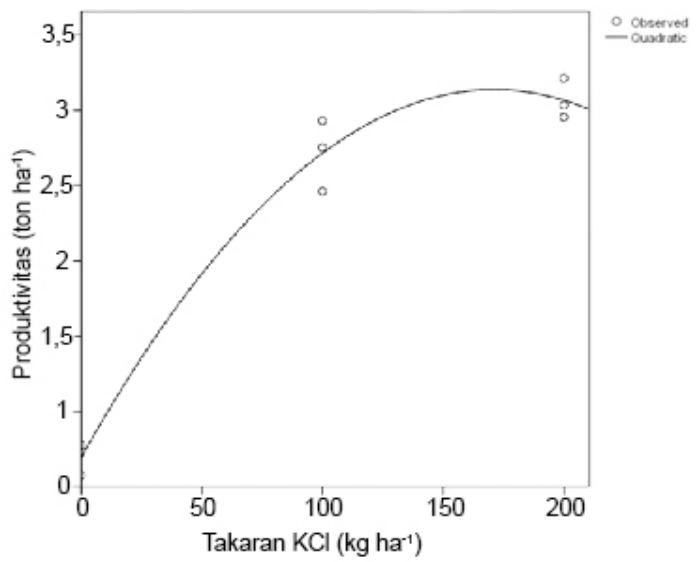

Figure 1. Regression of upland rice productivity as affected by trenches with organic matter

This regression analysis provided data on the best treatment combination to produce the highest productivity (yield) with the right fertilizer efficiency. The optimum $\mathrm{KCl}$ dose obtained from 
the interaction of both factors was $173.65 \mathrm{~kg} \cdot \mathrm{ha}^{-1}$, resulting in a productivity of 3.221 ton.ha ${ }^{-1}$. Based on the analysis of regression results, the fertilizer treatment dose higher than $173.65 \mathrm{~kg} \cdot \mathrm{ha}^{-1}$ tends to decrease the yield. Hence, through regression analysis, the right dose to produce the greatest yield could be obtained. The application of fertilizer must be carried out at the right dose according to the needs of the plant. The application of too little fertilizer results in the nutrient deficiency, whereas applying too much fertilizer can cause toxicity to to plants and increase output costs.

\section{CONCLUSION}

The application of trenches with organic matter increased the moisture content of the soil as much as $14 \%$ so that the water requirements of the plant were met, thereby affecting the growth, physiology, and the yield of upland rice plants. The $\mathrm{KCl}$ fertilization balanced the osmotic of plant tissue so that the cell becomes turgid. Such conditions improved the growth, physiology, and the yield of upland rice. The increase in plant growth could be seen from the length and area of roots and leaves, in which the combination of $\mathrm{KCl}$ fertilization treatment and trenches with organic matter significantly increased the growth of rice plants by an average of $10-21 \%$. Both treatments had interaction effect on moisture content, canopy and root dry weight, root length and area, photosynthetic rate, proline contents, and upland rice productivity. The upland rice plants treated with with a combination treatment of $\mathrm{KCl}$ fertilization and trenches with organic matter had the highest productivity, namely 3.068 tons.hectars ${ }^{-1}$, while those without both treatments had the productivity that was only 0.432 tons. hectars $^{-1}$. It means that with the combination of both treatments, water in the soil becomes more available to plants, thus increasing growth rate, improving physiology, and finally giving higher yield. Meanwhile, based on the regression analysis, a combination of trenches with organic matter and $\mathrm{KCl}$ at a dose of $173.65 \mathrm{~kg} \cdot \mathrm{ha}^{-1}$ gave the highest yield, namely 3,221 ton.ha-1.

\section{REFERENCES}

Asmin and La K. 2014. Kajian pemupukan kalium dengan aplikasi jerami padi terhadap pertumbuhan dan produksi padi di kabupaten buton, sulawesi tenggara. Jurnal agroteknos 4(3) : 180-188.

Astuti D, Damar S, Usfri R. 2019. Hubungan pupuk kalium dan kebutuhan air terhadap sifat fisiologis, sistem perakaran dan biomassa tanaman jagung (Zea mays). Jurnal Citra Widya Edukasi XI (1) : 67-76 ISSN. 2086-0412

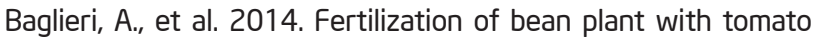
hydrolysates. Effect on biomass production, chlorophyll content and $n$ assimilation. Scientia Horticulturae, 176(1), 194-199.

Bahrami-rad, Sara \& Hajiboland R. 2017. Effect of potassium application in drought-stressed tobacco (Nicotiana rustica L.) Plants: Comparison of root with foliar application. Annals of agricultural science. 62:121-130

Cha-Um S, Takabe T \& Kirdmanee C. 2010. Osmotic potential, photosynthetic abilities and growth characters of oil palm seedlings in responses to polyethylene glycol-induced water deficit. Afr J of Biotechnol. 9(39) : 6509-6516.

Dien DC, Yamakawa T, Mochizuki T \& Htwe AZ. 2017. Dry weight accumulation, root plasticity, and stomatal conductance in rice (Oryza sativa L.) Varieties under Drought Stress and ReWatering Conditions. American Journal of Plant Sciences. 8: 189-3206

Dotto AC, Ricardo SDD, Alexandre C, Jean MCB. 2016. Potential of spectroradiometry to classify soil clay content. Scielo Bras. Ciênc. Solo. http://dx.doi.org/10.1590/18069657r bcs20151105

Ernita JE, Husna Y, Ardian. 2017. Pengaruh pemberian limbah serasah jagung terhadap pertumbuhan dan produksi tanaman jagung manis (Zea mays saccharata Sturt.) jom faperta

Fayyaz P, Etemadi E, Julaiee-Manesh N \& Zolfaghari R. 2013. Sodium and potassium allocation under drought stress in atlas mastic tree (Pistacia atlantica subsp. Mutica). Journal of Biogeosciences and Forestry 6:90-94.

Febriyono R, Yulia ES, Agus S. 2017. Peningkatan hasil tanaman kangkung darat (Ipomoea reptans, I.) melalui perlakuan jarak tanam dan jumlah tanaman per lubang. Vigor: Jurnal Ilmu Pertanian Tropika dan Subtropika 2 (1) : 22 - 27

Haryanti, S. 2014. Respon pertumbuhan jumlah dan luas daun nilam (Pogostemon cablin Benth) pada Tingkat Naungan yang Berbeda. Respon Pertumbuhan Jumlah 20-26

Hasanuzzaman M, et al., 2018. Potassium: A Vital Regulator of Plant Responses and Tolerance to Abiotic Stresses. Agronomy 8 (31) Idris A, Alona L, Aisha MA. 2017. Effect of light on the photosynthesis, pigment content and stomatal density of sun and shade leaves of vernonia amygdalina. International Journal of Engineering \& Technology. DOI: 10.14419/ijet.v7i4.30.22122 
Ikhsan, C.N, Baktiar, Efendi, dan Sabaruddin. 2017. Karakteristik hasil varietas/genotipe padi (Oriza sativa L.) terpilih di lahan tadah hujan. Prosiding Seminar Nasional Biotik. 2017

Jia., Y., Yang, X., Islam, E., \& Feng,Y. 2008. Effects of potassium deficiency on chloroplast ultrastructure and chlorophyll fluorescence in inefficient and efficient genotypes of rice. Journal Of Plant Nutrition, 31(1), 2105- 2118.

Kartikawati R and D Nursyamsi. 2013. Pengaruh pengairan, pemupukan, dan penghambat nitrifikasi terhadap emisi gas rumah kaca. Ecolab 7(1): 49-108.

Kementan. 2017. Outlook komoditas pertanian padi 2017. Pusat data dan sistem informasi pertanian. Kementerian Pertanian 2017. 119 hal

Kobayasi, K. 2012. Effects of solar radiation on fertility and flower opening time in rice under heat stress conditions. ISBN 978953-51-0384-4

Mawardi, Cut NI, Syamsuddin. 2016. Pertumbuhan dan hasil beberapa varietas tanaman padi (Oryza sativa L.) pada tingkat kondisi kekeringan. Jurnal IImiah Mahasiswa Pertanian Unsyiah 1(1): 176-187

Nurnasari E, and Djumali. 2010. Pengaruh kondisi ketinggian tempat terhadap produksi dan mutu tembakau temanggung. Buletin Tanaman Tembakau, Serat, dan Minyak Industri 2(2):45-59

Puspasari, E., christine W, Arief D., Irwan, S. 2017. Aspek sosial ekonomi pada sistem agroforestri di areal kerja hutan kemasyarakatan (Hkm) Kabupaten Lampung Barat, Provinsi Lampung. Jurnal Sylva Lestari. ISSN (online) 2549-5747

Rusli and Heryana, N. 2015. Dampak dan antisipasi kekeringan pada tanaman karet. SIRINOV 3(2): 83-92.

Saikia P., Amit K, Mohammed LK. 2017. Agroforestry: A sustainable land use system for livelihood security and climate change mitigation. Climate Change and Agroforestry. New India Publishing Agency, New Delhi, India.

Sitorus UKP, Balonggu S, Nini R. 2014. Respons pertumbuhan bibit kakao (Theobroma cacao I.) terhadap pemberian abu boiler dan pupuk urea pada media pembibitan. Jurnal Online Agroekoteknologi. 2(3) ISSN No. 2337- 6597

Soil Survei Staff. 2014. Keys to Soil Taxonomy 12Ed. Natural Resources Conservation Service. U.S. Department of Agriculture. Handbook 372.

Subagyono, K., T. Vadari, R. L. Watung, Sukristiyonubowo, and F. Agus. 2017. Managing soil erosion control in babon catchment, central java, indonesia: toward community-based soil conservation measures. Proceeding International Soil Conservation Organization (ISCO 2014). Brisbane, Australia, 4-8 July 2014.

Tarigan EE, jonis G, Meriani. 2013. Pertumbuhan dan produksi beberapa varietas padi gogo terhadap pemberian pupuk organik cair. Jurnal Online Agroteknologi 2(1): 113-120 ISSN No. 2337- 6597

Wahyuti, T.B. 2011. Pengaruh lengas tanah, pupuk kalium, dan pupuk kandang terhadap pertumbuhan dan hasil kedelai pada vertisol. UGM. Yogyakarta.

Widianto, A. 2013. Agroforestry dan peranannya dalam mempertahankan fungsi hidrologi dan konservasi. Forestry Research and Development.
Virmani, S.M., K.L. Sahrawat, and J.R. Burford. 2002. Physical and chemical properties of vertisols and their management. International Crops Research Institute for the Semi-Arid Tropics (ICRISAT), Patancheru, Andhra Pradesh, India.

Zain NAM, Ismail. MR, Puteh A., M. Mahmood and M.R. Islam. 2014. Drought tolerance and ion accumulation of rice following application of additional potassium fertilizer. Communications in Soil Science and Plant Analysis. 45:2502- 2514.

Zain NAM, Mohd RI, Maziah M, Adam P. 2014. Alleviation of water stress effects on mr220 rice by application of periodical water stress and potassium fertilization. J.Molecules. DOI: 10.3390/ molecules 19021795 